\title{
From feast to famine on the steppes
}

\author{
David P. MALLON
}

The Eurasian steppes, the grasslands extending from Hungary to northern China, are grazed by a suite of endemic ungulates that include Przewalski's horse Equus ferus, wild ass Equus hemionus, goitred gazelle Gazella subgutturosa, Mongolian gazelle Procapra gutturosa and saiga antelope Saiga tatarica. This ecosystem-a biodiversity coldspot (Entwistle, 2004)-has been fragmented and degraded through overgrazing and conversion to agriculture. Much of the literature on this ecosystem is in Russian but valuable contributions in English were made by two of the greatest authorities on the ecology of this region. Dementiev (1956) reviewed wildlife conservation in the USSR, and Bannikov (1977) underlined the importance of the expanding system of zapovedniks (strict nature reserves) in the recovery of species that had been depleted by overhunting, including the saiga antelope.

Both the Mongolian gazelle and saiga antelope have been hunted for their meat, hides and the horns of the males, and in more recent times they have been exploited for commercial harvests. Crawford (1972) advocated the saiga as an ideal species for a sustainable, large-scale harvest.

Although both species are susceptible to mass die-offs from disease and extreme weather, their fortunes have diverged. The nomadic Mongolian gazelle still dwells in huge herds on the Daurian steppes of eastern Mongolia and neighbouring areas of China and Russia. Although its range is only c. $25 \%$ of its former extent in China as a result of uncontrolled hunting (Wang et al., 1997) and has shrunk similarly in Mongolia, numbers remain high, with estimates of 400,000 in 1989 and $>2$ million in 1994 (Lhagvasuren \& MilnerGulland, 1997). A 2000-2002 survey estimated the population to be 500,000-1,500,000 (Olson et al., 2005), and a herd of c. 200,000 was recorded in 2007 (Olson et al., 2009).

Such wide variations in numbers illustrate the logistical and methodological issues involved in estimating the population size of ungulates that have extensive ranges and clumped distributions. These issues are often compounded by poor study design, inadequate sampling, and failure to appreciate sources of error and bias or to account for detectability (Singh \& Milner-Gulland, 2011).

There are five saiga populations, and the Mongolian subspecies $S$. tatarica mongolica, which is isolated by the Altai mountains, is genetically distinct, whereas the other populations (of S. tatarica tatarica), in Kalmykia, Russia, Kazakhstan and Uzbekistan, are polyphyletic, consistent

David P. Mallon Division of Biology and Conservation Ecology, Manchester Metropolitan University, Chester St., Manchester, M1 5GD, UK

E-mail d.mallon@zoo.co.uk with recent fragmentation and population declines (Kholodova et al., 2006). Two key attributes of the saiga are the horns of the males, which are valued in traditional Asian medicine, and that females can mate at 7-8 months and commonly bear twins, and thus the species is capable of rapid population increases. Tragically, however, excessive hunting reduced herds numbering in the millions to c. 1,000 by the early 20 th century. The species received legal protection in 1919, however, and benefited from subsequent protection measures (Dementiev, 1956; Bannikov, 1977). The scale of the recovery was spectacular (Linnard, 1963): by 1960 saiga numbers had reached 540,000 in Russia and 1,300,000 in Kazakhstan, with harvests resuming in 1951 and 1954, respectively, on an industrial scale; west of the Volga 120,000-150,000 saiga were harvested per year during 1957-1962. Quotas were set to avoid overharvesting of males, and the regulated harvest continued until 1990. Soon after, however, came the first indications that all was not well, with reports from Russia of a population decline and excessive poaching of males (MilnerGulland, 1994).

The dissolution of the USSR in 1991 and the switch from a centralized to a market economy resulted in the withdrawal of subsidies and protected area budgets, the collapse of nature protection systems, and an economic crisis. International borders opened up, enhancing the opportunities for trading saiga horn. The impact was catastrophic: poachers flooded into saiga range to obtain horns, and large numbers were killed locally for meat. The largest population fell to $4 \%$ of its 1990 size and other populations also suffered large reductions (Milner-Gulland et al., 2001). Evidence from Russia pointed to selective harvesting, with a small proportion of adult males and many females without young, bringing the population close to reproductive collapse (Milner-Gulland et al., 2001).

The full scale of the disaster, and the response, was set out by Arylov et al. (2004). Most populations of saiga were declining, with that in Kazakhstan having fallen to 21,000 in 2003. In 2002 saiga moved directly from the lowest category of threat on the IUCN Red List to the highest, Critically Endangered, and a Convention on Migratory Species Saiga Memorandum of Understanding and action plan were developed. Substantial investments were made in anti-poaching, aerial surveys, and protected areas in Kazakhstan, and an emergency decree was passed in Russia, actions supported by national and international NGOs and by CITES.

For the Endangered Mongolian saiga, Young et al. (2010) estimated 4,938 and 7,221 in 2006 and 2007, 
respectively, although the confidence intervals were wide. The most recent population estimate is c. 15,000 and, although the use of different census methods precludes direct comparisons with previous surveys, the population may be growing (Milner-Gulland, 2015). A target of 20,000 Mongolian saiga by 2020 , set in a 2007 conservation planning workshop (WCS, 2008), could therefore be attained.

As a result of conservation measures $S$. tatarica tatarica stabilized or increased overall (Milner-Gulland, 2010). The largest population, in Betpak-dala, Kazakhstan, grew $76 \%$ annually during 2003-2010, again demonstrating the resilience of the species and the value of an internationally supported conservation programme. This news was balanced in part by setbacks in three other populations: poaching and other factors reduced saiga numbers in Russia and caused a $47 \%$ decrease in Ustiurt during 2009-2010, and in May 2010 a disease outbreak killed c.12,ooo saiga in the Ural population, a $31 \%$ loss. Nevertheless, numbers increased overall and by spring 2015 there were $>250,000$ saiga in Kazakhstan, plus a few thousand in Russia. Then, in September 2015, another mass die-off occurred in Betpak-dala, with at least 134,252 ( $62 \%$ of that population) dying in 3 weeks (Milner-Gulland, 2015). The cause appeared to be Pasteurella interacting with as yet unidentified environmental triggers, similar to the die-off in 2010.

Twice in the last 100 years the saiga antelope has rebounded from critically low levels following protection from overhunting. Only time will tell if it can recover again while coping with the emerging threats of disease and environmental change but there is cause for hope (Milner-Gulland, 2015). The other abundant species of the steppes, the Mongolian gazelle, is currently categorized as Least Concern on the IUCN Red List but faces a series of potential threats that leave no room for complacency.

These two species have not undergone the same crisis as that faced by the Arabian oryx Oryx leucoryx, formerly extinct in the wild (Fisher, 2016). However, the task is not just to prevent their extinction but also to conserve their large herds and nomadic and migratory character, features that cannot be replicated in miniature or preserved in captivity. These species are also an integral component of the steppe ecosystem, a sustainable resource if managed appropriately, and a part of the culture of Central Asia, whose peoples retain an interest in their conservation (Howe et al., 2012). The sometimes vast numbers of these two species are a reminder of the importance of abundance as a conservation value (Redford et al., 2013) - such huge herds are a spectacle that can inspire and build connections with the natural world, both among conservationists and the public.

To mark Volume 50 of Oryx this Editorial and the references cited herein are freely available as a virtual issue of the journal at http://journals.cambridge.org/orx

\section{Acknowledgements}

I thank Martin Fisher and E.J. Milner-Gulland for their comments and critiques.

\section{References}

Arylov., Y., Badmaev, V., Bekenov, A., Chimeg, J., Entwistle, A., Grachev, Y.A. et al. (2004) The saiga antelope-teetering on the brink but still cause for hope. Oryx, 38, 250-251.

B ANnikov, A. G. (1977) Wildlife protection in the USSR. Oryx, 14, 123128.

Crawford, M. (1972) Conservation by utilisation. Oryx, 11, 427-432.

Dementiev, G.P. (1956) Nature protection in the U.S.S.R. Oryx, 3, 331333.

Entwistle, A. (2004) Eurasia-a biodiversity coldspot? Oryx, 38, 239240.

Fisher, M. (2016) Fall, resurrection and uncertainty: an Arabian tale. Oryx, 50, 1-2.

Howe, C., Obgenova, O. \& Milner-Gulland, E.J. (2012) Evaluating the effectiveness of a public awareness campaign as a conservation intervention: the saiga antelope Saiga tatarica in Kalmykia, Russia. Oryx, 46, 269-277.

Kholodova, M., Milner-Gulland, E.J., Easton, A.J., Amgalan, L., Arylov, I.A., Bekenov, A. et al. (2006) Mitochondrial DNA variation and population structure of the Critically Endangered saiga antelope Saiga tatarica. Oryx, 40, 103-107.

Lhagvasuren, B. \& Milner-Gulland, E.J. (1997) The status and management of the Mongolian gazelle Procapra gutturosa population. Oryx, 31, 127-134.

Linnard, W. (1963) The saiga. Oryx, 7, 30-33.

Milner-Gulland, E.J. (1994) Sustainable management of the saiga antelope. Oryx, 28, 257-262.

Milner-Gulland, E.J. (2010) Saiga antelope suffers three blows. Oryx, 44, 477-478.

Milner-Gulland, E.J. (2015) Catastrophe and hope for the saiga. Oryx, 49, 577-577.

Milner-Gulland, E.J., Kholodova, M.V., Bekenov, A., Bukreeva, O.M., Grachev, I.A., Amgalan, L. \& Lushchekina, A.A. (2001) Dramatic declines in saiga antelope populations. Oryx, $35,340-345$.

Olson, K.A., Fuller, T.K., Schaller, G.B., Odonkhuu, D. \& Murray, M. (2005). Population density of Mongolian gazelles as estimated by driving long-distance transects. Oryx, 39, 164-169.

Olson, K.A., Mueller, T., Bolortsetseg, S., Leimgruber, P., FAGAN, W.F. \& FULLER, T.K. (2009) A mega herd of more than 200,00o Mongolian gazelle Procapra gutturosa: a consequence of habitat quality. Oryx, 43, 149-153.

Redford, K.H, Berger, J. \& ZACK, S. (2013) Abundance as a conservation value. Oryx, 47, 157-158.

SinGH, N.J. \& Milner-Gulland, E.J. (2011) Monitoring ungulates in Central Asia: current constraints and future potential. Oryx, 45, $38-49$.

WANG, X., Sheng, H., BI, J. \& LI, M. (1997) Recent history and status of the Mongolian gazelle in Inner Mongolia, China. Oryx, 31, 120-126.

WCS (Wildlife Conservation Society) (2008) Mongolian Saiga Conservation Workshop. Oryx, 42, 14-15.

Young, J.K., Murray, K.M., StrindberG, S., Buuveibatatar, B. \& Berger, J. (2010) Population estimates of Endangered Mongolian saiga Saiga tatarica mongolica: implications for effective monitoring and population recovery. Oryx, 44, 285-292. 